Original article

\title{
EFFECTS OF DIETARY GARLIC (ALLIUM SATIVUM) MEAL ON SKIN THICKNESS AND FAT DEPOSITION IN COMMERCIAL BROILER CHICKENS
}

\author{
O. O. OGUNLESI ${ }^{1}$, O. A. OLADELE ${ }^{1}$, O. O. AINA ${ }^{2} \&$ O. O. ESAN ${ }^{1}$ \\ ${ }^{1}$ Department of Veterinary Medicine, Faculty of Veterinary Medicine, \\ University of Ibadan, Nigeria; ${ }^{2}$ Department of Veterinary Anatomy, \\ Faculty of Veterinary Medicine, University of Ibadan, Nigeria
}

\section{Summary}

Ogunlesi, O. O., O. A. Oladele, O. O. Aina \& O. O. Esan, 2017. Effects of dietary garlic (Allium sativum) meal on skin thickness and fat deposition in commercial broiler chickens. Bulg. J. Vet. Med., 20, No 2, 118-124.

\begin{abstract}
Excessive deposition of fat in the skin of commercial chickens has major implications on human health. Garlic (Allium sativum) has been reported to have hypolipidaemic effect in animals. The effect of garlic on fat deposition in the skin of commercial broilers was therefore investigated. One hundred and sixty day-old Arbor acres broilers of different sexes were randomly separated into four groups. Group A was fed a plain ration; group B had $0.125 \%$ garlic meal (GM) in feed continuously, group C $-0.125 \% \mathrm{GM}$ at pulse inclusion (on for 2 weeks and off for 2 weeks) and group D $-0.25 \% \mathrm{GM}$ continuously. At 4 and 8 weeks of age, five broilers per group were randomly selected, euthanised and back cape skin sections were harvested and processed for histology. Epidermal as well as dermalhypodermal thicknesses were measured. Data were statistically analysed using Duncan's multiple range test and Student's $t$-test at $\mathrm{P}<0.05$. The epidermis in the control group (Group A) was significantly different vs the other groups at 8 weeks of age. Dermal-hypodermal thickness of group $\mathrm{C}$ $(15296.1 \pm 965.7 \mu \mathrm{m})$ was significantly higher vs other groups at 4 weeks of age. Fat globules were relatively more abundant in the hypodermis of group A at 4 and 8 weeks of age, while collagen fibres in the dermis were relatively denser in the GM-supplemented groups. It was concluded that garlic inclusion in feed of commercial broilers resulted in thinner epidermis and denser collagen fibres in the dermis causing thicker dermis-hypodermis, as well as decreased fat deposits in the hypodermis.
\end{abstract}

Key words: broiler chickens, garlic, fat deposition, skin thickness

\section{INTRODUCTION}

Increased growth rate and low feed conversion ratio through genetic selection in broiler chicken has been attributed to increased body fat deposition, high morta- lity and high incidence of metabolic diseases and skeletal disorders (Zubair \& Leeson, 1996). Excessive fat (abdominal and subcutaneous) in carcasses of broiler 
chickens is a waste product in slaughterhouses since it reduces carcass yield and feed efficiency (Lippens, 2003; Jennen, 2004), causes meat rejection by the consumers (Kessler et al., 2000), as well as brings about significant economic losses (Havenstein et al., 2003; Nikolova et al., 2007). Also, consumer awareness of the relationship between consumption of certain fat and cardiovascular diseases has resulted in preference for leaner meat (Cable \& Waldroup, 1990), thus stimulating interest in reducing body fat deposition in broiler production. Nonetheless, a minimum quantity of carcass fat is necessary for an optimal sensory quality because of its positive influence on succulence and taste (Lippens, 2003; Zerhdaran et al., 2004; Zerhdaran, 2005).

Garlic (Allium sativum) is regarded as a therapeutic agent in the traditions of many cultures (Amagase et al., 2001). The active component of garlic has some beneficial effects for livestock, having hypocholesterolaemic effects, growth promoting and antioxidant activities (Lewis et al., 2003; Oladele et al., 2012). It has been reported to decrease the concentration of triglycerides and cholesterol in blood (Gorunovic, 2001), and to possess anticholesterolaemic and anti-lipidaemic actions proven experimentally in rabbits and rats (Sovová \& Sova, 2004). Feeding garlic powder results in lower plasma cholesterol as well as breast and thigh muscles cholesterol in broilers (Konjufca et al., 1997). Garlic supplementation can be valuable in the production of quality broiler meat as suggested by Sklan et al. (1992). It is known to improve the activity of enzymes which are involved in the conversion of cholesterol to bile acids (Raeesi et al., 2010), thus, it could be valuable in the reduction of lipids in body tissues. The biochemically active con- stituent of garlic is allicin (thio-2-propene1 -sulfinic acid S-allyl ester) which is produced from an odourless precursor alliin, catalysed by the enzyme alliinase or alliin lyase and is responsible for its smell (Murad \& Baseer, 1997). Barhagallo et al. (1998) reported that chronic exposure to small amounts of tellurium found in garlic may reduce endogenous cholesterol production through inhibition of hepatic squalene epoxidase.

The present study was therefore carried out to determine the effect of dietary garlic supplementation on subcutaneous fat deposition in chicken in order to improve carcass quality and consumer acceptance.

\section{MATERIALS AND METHODS}

\section{Experimental chickens and maintenance}

One hundred and sixty Arbor acres dayold broilers of different sexes were purchased from a commercial hatchery in Ibadan, Nigeria. The chicks were reared at the Experimental Animal Unit of the Department of Veterinary Medicine, University of Ibadan (N 07.27121, E 003.50661). The altitude was 815 metres above sea level with relative humidity ranging from $50-80 \%$, having a rainfall of approximately 70 inches per annum and temperatures ranges between $28{ }^{\circ} \mathrm{C}$ and $34^{\circ} \mathrm{C}$.

They were randomly separated into 4 treatment groups (A, B, C and D) of forty birds each and reared in different cages for 8 weeks. The chicks were fed ad libitum with broiler starter ration (from dayold to 4 weeks of age) and broiler finisher ration (from 5 to 8 weeks of age) supplemented with varying levels of garlic meal (GM, Patent No. NG/2012/285). The broilers were administered multivitamins in drinking water between 1-5 days of age and prophylactic dose of doxycycline hyc- 
Effects of dietary garlic (Allium sativum) meal on skin thickness and fat deposition in commercial ....

late and gentamicin sulphate $\left(\right.$ Gendox ${ }^{\circledR}$, Pantex Holland Veterinary pharmaceutical company) from 6-11 days of age. Newcastle disease (ND) vaccine, $\mathrm{HB}_{1}$ strain was administered on day 1 and LaSota strain at 21 days of age, while infectious bursal disease vaccine was administered at 8 and 17 days of age.

\section{Experimental procedure}

Broilers in Group A were fed plain ration, those in Group B were fed ration containing $0.125 \%$ GM continuously, those in Group $\mathrm{C}$ were fed ration containing $0.125 \% \mathrm{GM}$ for 2 weeks on and 2 weeks off (pulse dosing), while those in Group D were fed ration with $0.25 \%$ GM continuously, till 8 weeks of age. At 4 and 8 weeks of age, five broilers per group were randomly selected and euthanised in $\mathrm{CO}_{2}$ chamber. Sections of skin at the region of the back cape were cut, and fixed in labelled sample bottles containing 10\% formalin.

Histological sections were processed and stained with haematoxylin \& eosin stain. From each section, increase in the thickness of collagen fibres was microscopically visualised while epidermal and dermal-hypodermal thicknesses as well as hypodermal and adipocytes layer thick- nesses were measured with a micro-meter using the motic image scale under the microscope with a graduated eye piece of $\times 100$ objective lens. The percent ratios of the adipocytes layer to the total thickness of the hypodermis and of adipocytes layer to the total thickness of dermal+hypodermal layers were calculated.

\section{Statistical analysis}

Mean and standard error of mean values were calculated for each group and comparisons between and within groups for significant differences were made using analysis of variance, Duncan's multiple range test and Student's $t$-test.

\section{RESULTS}

The epidermal thickness in group A (control group) was significantly $(\mathrm{P}<0.05)$ higher in 8-week-old birds compared to all other groups (Table 1). The epidermal thickness decreased significantly $(\mathrm{P}<0.05)$ in group $\mathrm{C}$ at 4 weeks of age vs the same group at 8 weeks of age (Table 1). Similarly, the epidermal thickness decreased significantly $(\mathrm{P}<0.05)$ in birds from group $\mathrm{D}$ at 4 weeks to birds in the same group at 8 weeks of age (Table 1). The dermal-

Table 1. Epidermal thickness and dermal-hypodermal thickness (mean \pm SEM; $n=5$ ) in commercial broilers at 4 and 8 weeks of age fed varying levels of garlic meal (GM): Group A - plain ration, Group B $-0.125 \%$ GM continuously, Group C - 0.125\% GM for 2 weeks on and 2 weeks off (pulse dosing), Group D - $0.25 \%$ GM continuously

\begin{tabular}{lclrr}
\hline \multicolumn{1}{c}{ Group A } & Group B & Group C & Group D \\
\hline Epidermal thickness $(\mu \mathrm{m})$ & & & \\
4 weeks & $1675.9 \pm 199.9^{\mathrm{a}}$ & $1538.4 \pm 163.6^{\mathrm{a}}$ & $1279.7 \pm 173.4^{\mathrm{a}}$ & $1368.7 \pm 209.2^{\mathrm{a}}$ \\
8 weeks & $1566.7 \pm 354^{\mathrm{a}}$ & $1241.4 \pm 225.7^{\mathrm{ab}}$ & $851.5 \pm 101.7^{\mathrm{b}}$ & $989.1 \pm 87.4^{\mathrm{ab}}$ \\
\hline \multicolumn{2}{l}{ Dermal-hypodermal thickness $(\mu \mathrm{m})$} & & & \\
4 weeks & $9927.1 \pm 1285.6^{\mathrm{b}}$ & $13603.2 \pm 1754.9^{\mathrm{ab}}$ & $15296.1 \pm 965.7^{\mathrm{a}}$ & $11194.3 \pm 936.4^{\mathrm{b}}$ \\
8 weeks & $11700.4 \pm 1600.6^{\mathrm{a}}$ & $14512.2 \pm 1252.6^{\mathrm{a}}$ & $14430.7 \pm 912.6^{\mathrm{a}}$ & $14159.5 \pm 2132.7^{\mathrm{a}}$ \\
\hline
\end{tabular}

Values in the same row with different superscript are significantly different $(\mathrm{P}<0.05)$. 
Table 2. Adipocyte layer and hypodermal layer thickness (mean $\pm S E M ; n=5)$ in commercial broilers at 4 and 8 weeks of age fed varying levels of garlic meal (GM): Group A - plain ration, Group B $0.125 \%$ GM continuously, Group C $-0.125 \%$ GM for 2 weeks on and 2 weeks off (pulse dosing), Group D $-0.25 \%$ GM continuously

\begin{tabular}{lcccc}
\hline & Group A & Group B & Group C & Group D \\
\hline $\begin{array}{l}\text { Adipocyte layer, } \mu \mathrm{m} \\
\text { 4 weeks of age }\end{array}$ & $4808.4 \pm 1046.1$ & $4016.2 \pm 551.5$ & $2574.1 \pm 454.9$ & $4978.1 \pm 469.7$ \\
$\begin{array}{l}\text { Hypodermal layer, } \mu \mathrm{m} \\
\text { 4 weeks of age }\end{array}$ & $1824.5 \pm 350.7$ & $1603.4 \pm 409.2$ & $1742.2 \pm 376.2$ & $2248.4 \pm 433$ \\
$\begin{array}{l}\text { Adipocyte layer, } \mu \mathrm{m} \\
\text { 8 weeks of age }\end{array}$ & $3492.8 \pm 496.6$ & $3246.6 \pm 1228.3$ & $2353.3 \pm 356.2$ & $3677.5 \pm 344.3$ \\
$\begin{array}{l}\text { Hypodermal layer, } \mu \mathrm{m} \\
\text { 8 weeks of age }\end{array}$ & $2253.7 \pm 298.7$ & $1673.1 \pm 310.6$ & $1429.2 \pm 240.3$ & $2208.0 \pm 671.1$ \\
\hline
\end{tabular}

Table 3. Percent ratios of adipocytes to total of hypodermal and dermal hypodermal thicknesses (mean \pm SEM; $n=5$ ) in commercial broilers at 4 and 8 weeks of age fed varying levels of garlic meal (GM): Group A- plain ration, Group B $-0.125 \%$ GM continuously, Group C $-0.125 \%$ GM for 2 weeks on and 2 weeks off (pulse dosing), Group D- $0.25 \%$ GM continuously

\begin{tabular}{lcrrr}
\hline & Group A & Group B & Group C & Group D \\
\hline $\begin{array}{l}\text { Adipocytes layer/hypodermis } \\
\text { thickness percentage, }\end{array}$ & $325.4 \pm 104.7^{\mathrm{a}}$ & $274.2 \pm 30.1^{\mathrm{a}}$ & $190.8 \pm 50^{\mathrm{a}}$ & $292.2 \pm 101.7^{\mathrm{a}}$ \\
$\begin{array}{l}\text { 4 weeks of age } \\
\begin{array}{l}\text { Adipocytes layer/hypodermis }+ \\
\text { dermis thickness percentage, }\end{array}\end{array}$ & $47.3 \pm 7.2^{\mathrm{b}}$ & $29.7 \pm 1.6^{\mathrm{a}}$ & $16.7 \pm 2.5^{\mathrm{a}}$ & $46.2 \pm 6.9^{\mathrm{b}}$ \\
$\begin{array}{l}4 \text { weeks of age } \\
\begin{array}{l}\text { Adipocytes layer/hypodermis } \\
\text { thickness percentage, }\end{array}\end{array}$ & $170 \pm 33.1^{\mathrm{a} *}$ & $199.9 \pm 72.5^{\mathrm{a}}$ & $174.9 \pm 30.9^{\mathrm{a}}$ & $237.8 \pm 80.7^{\mathrm{a}}$ \\
$\begin{array}{l}\text { 8 weeks of age } \\
\text { Adipocytes layer/hypodermis }+ \\
\text { dermis thickness percentage, }\end{array}$ & $31 \pm 4.9^{\mathrm{a}}$ & $22.2 \pm 8^{\mathrm{a}}$ & $16 \pm 1.7^{\mathrm{a}}$ & $34.2 \pm 3.3^{\mathrm{a}}$ \\
8 weeks of age & & & & \\
\hline
\end{tabular}

Values in the same row with different superscript are significantly different $(\mathrm{P}<0.05)$; *significantly lower than value for 4 weeks-old birds.

hypodermal thickness in group $\mathrm{C}$ was significantly higher $(\mathrm{P}<0.05)$ than the respective value in group $\mathrm{A}$ at 4 weeks of age (Table 1).

No significant differences were found out with respect to adipocyte and hypodermal layer thicknesses (Table 2).

The percentage of adipocytes to the total dermal-hypodermal thickness was significantly lower $(\mathrm{P}<0.05)$ in Groups $\mathrm{B}$ and $\mathrm{C}$ (fed $1.25 \mathrm{~g} / \mathrm{kg} \mathrm{GM}$ ) than the value in controls (A) at 4 weeks of age (Table 3).
Histological examination of skin sections showed thinner epidermis in all garlic meal fed groups B, C and D (Fig. 1) compared with control Group A (Fig. 2). The dermis-hypodermis of garlic meal fed groups was thicker than those of control Group A which had more abundant fat globules (Fig. 2). Also, thicker collagen fibres were observed in GM groups (Fig. 1) unlike the scanty appearance in control group A (Fig. 2). 


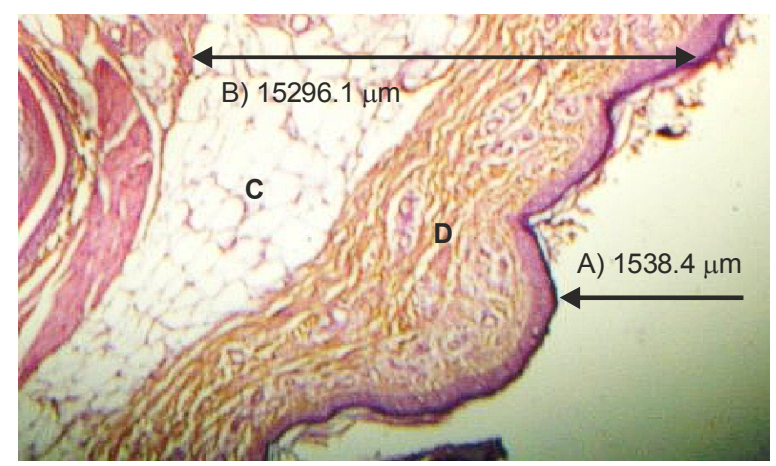

Fig. 1. Photomicrograph of the skin of broilers from Group C $(1.25 \mathrm{~g} / \mathrm{kg}$ garlic inclusion at pulse dose) at 4 weeks of age showing (A) thinner epidermis; (B) thicker dermal-hypodermal layer with fat globules (C); (D) collagen fibres $(H \& E) \times 100$.

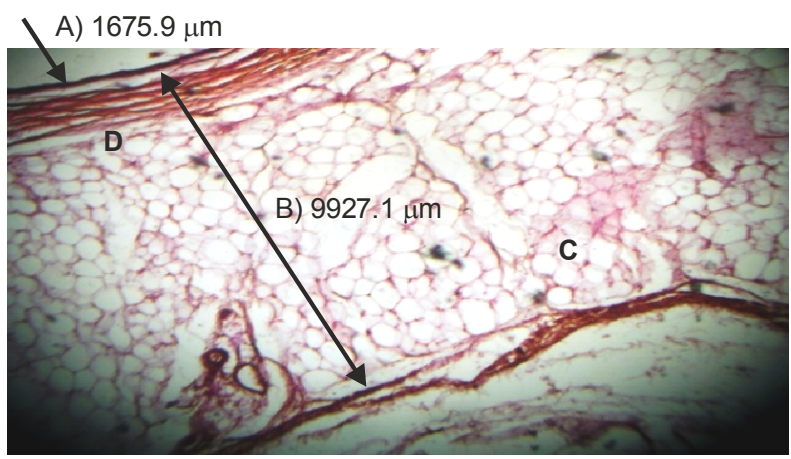

Fig. 2. Photomicrograph of the skin of broilers from Group A (control) at 4 weeks of age showing (A) thicker epidermis; (B) thinner dermal-hypodermal thickness with fat globules (C); (D) collagen fibres $(H \& E) \times 100$.

\section{DISCUSSION}

This study was conducted to determine the skin thickness and fat deposition in garlic inclusion and non-inclusion commercial broilers. Thicker epidermis as recorded for control group $\mathrm{A}$ at 4 and 8 weeks of age compared with the garlic meal groups (B, C and D) was probably due to a very thick surface layer of dead cells in the epidermis which was absent in garlic groups due to exfoliation. Furthermore, the thicker dermis-hypodermis layer of the skin largely recorded for the garlic groups at both 4 and 8 weeks of age was a result of the thicker collagen present in their dermis compared to that of the control group. Lisa (2014) reported that sulfur containing amino acids i.e. methionine and cysteine (both of which are present in garlic) build up collagen and prevent damage to it. Collagen, which is the main structural protein in the skin, provides the structural scaffolding for cells, tissues, and organs (Draelos, 2015). It gives the skin its strength, durability and is also responsible for the replacement of dead skin cells (Mcintosh, 2014). Moon (2006) also reported that collagen is the major component of intramuscular connective tissue associated with meat tenderness, while meat tenderness is a very important 
trait of meat quality and consumer acceptance, and this is dependent on textural characteristics and composition of the meat (Nhat Thu, 2006). Furthermore, Muir et al. (2000) and Monson et al. (2005) argued that meat tenderness is a relationship between the collagen content, heat stability and the myofibrillar structure of muscle. As reported by Young \& Braggins (1993), sensory tenderness and shear force of meat are functions of total collagen content. The shear force is an indicator of the easy cut measure of the meat and inidicating its tenderness (Platter et al., 2003). Likewise, the observed reduction in fat in the skin of broilers in the garlic groups confirms the lipolytic effect of garlic (Keefer, 2013).

This study has shown that garlic inclusion in feed particularly at a dose of $0.125 \%$ given either continuously or by pulse-dosing has the ability to bring about thinner epidermis, thicker collagen in the dermis and decreased fat deposits in the hypodermis resulting from thicker dermishypodermis.

\section{REFERENCES}

Amagase, H., B. L. Petesch, H. Matsuura, S. Kasuga \& Y. Itakura, 2001. Intake of garlic and its bioactive components. Journal of Nutrition 131, 955S-962S.

Barhagallo, C. M., M. R. Averna, G. Frada, D. Noto, G. Cavera \& A. Notarbartolo, 1998. Lipoprotein profile and HDL: Subfractions distributions in centenarians. $\mathrm{Ge}$ rontology, 44, 106-110.

Draelos, Z. D., 2015. Collagen: The skin structural protein. NUSKIN. http://www. nuskin.com/en_ZA/corporate/company/scienc e/skin_care_science/collagen.html (15 January 2016, date last accessed).

Cabel, M. C. \& P. W. Waldroup, 1990. Effect of different nutrient restriction programs early in life on broiler performance and abdominal fat content. Poultry Science, 69 , 652-660.

Gorunovic, M. B., 2001. Farmakognozija, Beograd pp. 672-680.

Havenstein, G. B., P. R. Ferket \& M. A. Quereshi, 2003. Growth, livability, and feed conversion of 1957 versus 2001 broilers when fed representative 1957 and 2001 broiler diets. Poultry Science, 82, $1500-1508$.

Jennen, D. G. J., 2004. Chicken fatness from QTL to candidate gene. Ph.D. thesis, Wageningen University, The Netherlands, pp. 176.

Keefer, A., 2013. Does garlic speed up metabolism? Fat breakdown. Livestrong.com. www.livestrong.com/article/51075-garlicspeed-up-metabolism. (15 January 2016, date last accessed).

Kessler, A. M., P. N. Snizek. Jr \& I. Brugalli, 2000. Manipulação da quantidade de gordura na carcaça de frangos. In: Anais da Conferência APINCO de Ciência e Tecnologia Avícolas. APINCO, Campinas, SP, Brazil, pp. 107-133.

Konjufca, V. H., G. M. Pesti \& R. I. Bakalli, 1997. Modulation of cholesterol levels in broilers meat by dietary garlic and copper. Poultry Science, 76, 1264-1271.

Lewis, M. R., S. P. Rose, A. M. Mackenzie \& L. A. Tucker, 2003. Effects of dietary inclusion of plant extracts on the growth performance of male broiler chickens British Poultry Science, 44 (Suppl.1), 543-544.

Lippens, M. 2003. The influence of feed control on the growth pattern and production parameters of broiler chicken. Ph.D. thesis, Gent University, Belgium, pp. 203.

Lisa, T., 2014.The benefits of MSM (Methylsulfonyl-methane), http://www.zerbos.com /common/news/store_news.asp?task=store news\&SID store news $=72 \&$ store $I D=5$ DDC50E796734E49AEDE162FFC8CAB F9 (27 January 2016, date last accessed).

Mcintosh, J., 2014. What is collagen? What does collagen do? Medical News Today. http://www.medicalnewstoday.com/articles 
Effects of dietary garlic (Allium sativum) meal on skin thickness and fat deposition in commercial ....

/262881.php. (15 January 2016, date last accessed).

Monson, F., C. Sanudo \& I. Sierra, 2005. Influence of breed and ageing time on the sensory meat quality and consumer acceptability in intensively reared beef. Meat Science, 71, 471-479.

Moon, S. S., 2006. The effect of quality grade and muscle on collagen contents and tenderness of intramuscular connective tissue and myofibrillar protein for Hanwoo beef. Asian-Austrialian Journal of Animal Science, 19, 1059-1064.

Muir, P. D., G. J. Wallace, P. M. Dobbie \& M. D. Bown, 2000. A comparison of animal performance and carcass and meat quality characteristics in Hereford, Hereford $\times$ Friesian, and Friesian steers grazed together at pasture. New Zealand Journal of Agricultural Research, 43, 193-205.

Murad, K. \& A. Baseer, 1997. Garlic (Allium sativum): A review of controlled studies. Hamdard Medicus, 11, 13-15.

Nhat-Thu, D. T., 2006. Meat quality: Understanding of meat tenderness and influence of fat content on meat flavor. Science \& Technology Development, 9, 65-70.

Nikolova N., Z. Pavlovski, N. Milošević \& L. Perić, 2007. The quantity of abdominal fat in broiler chicken of different genotypes from fifth to seventh week of age. Biotechnology in Animal Husbandry, 23, 331338.

Oladele, O. A., B. O. Emipke, \& H. Bakare, 2012. Effect of dietary garlic (Allium sativum Linn) supplementation on body weight and gut morphometry of commercial broilers. International Journal of Morphology, 30, 238-240.

Platter, W. J., J. D. Tatum, K. E. Belk, P. L. Chapman, J. A. Scanga \& G. C. Smith. 2003. Relationships of consumer sensory ratings, marbling score, and shear force value to consumer acceptance of beef strip loin steaks. Journal of Animal Science, 81, 2741-2750.

Raeesi, M., S. A. Hoeini-Aliabad, A. Roofchaee, A. Zare-Shahneh, \& S. Pirali, 2010.
Effect of periodically use of garlic (Allium sativum) powder on performance and carcass characteristics in broiler chickens. World Academy of Science, Engineering \& Technology, 68, 1213-1219.

Sklan, D., Y. N. Berner \& H. D. Rabinowitch, 1992. The effect of dietary onion and garlic on hepatic lipid concentrations and activity of antioxidative enzymes in chicks, Journal of Nutrition and Biochemistry, 3, 322-325.

Sovová, M. \& P. Sova, 2004. Pharmaceutical importance of Allium sativum L. 5. Hypolipidemic effects in vitro and in vivo. Ceská a slovenská farmacie, 53, 117-123.

Young, O. A. \& T. J. Braggins, 1993. Tenderness of ovine semi membranosus. Is collagen concentration or solubility the critical factor? Meat Science, 35, 213-222.

Zerhdaran, S., 2005. Genetic improvement for production and health in broilers. Ph.D. thesis. Animal Breeding and Genetics Group, Department of Animal Science, Wageningen University, Wageningen, The Netherlands, pp. 132.

Zerhdaran, S., A. L. J. Vereijken, J. A. M. Van arendonk, \& E. H. Van der waaij, 2004. Estimation of genetic parameters for fat deposition and carcass traits in broilers. Poultry Science. 83, 521-525.

Zubair, A. K. \& S. Leeson, 1996. Compensatory growth in the broiler chicken: a review. World Poultry Science Journal, 52, 189-201.

Paper received 06.10.2015; accepted for publication 12.11.2015

\section{Correspondence:}

Dr. Oluwaseun O. Esan

Avian Diseases Unit,

Department of Veterinary Medicine

University of Ibadan, Ibadan, Nigeria.

+2348077898 811; +2348069217610

e-mail: oiuseunsol@yahoo.co.uk 